8-2009

\title{
Parental Divorce: A Protection from Later Delinquency for Maltreated Children
}

Christopher A. Mallett

Cleveland State University, c.a.mallett@csuohio.edu

Patricia A. Stoddard Dare

Cleveland State University, p.stoddarddare@csuohio.edu

Follow this and additional works at: https://engagedscholarship.csuohio.edu/clsowo_facpub

Part of the Criminology Commons, Family, Life Course, and Society Commons, Social Control, Law, Crime, and Deviance Commons, and the Social Work Commons

How does access to this work benefit you? Let us know!

Publisher's Statement

(c)Journal of Divorce \& Remarriage is the property of Taylor \& Francis Ltd

\section{Recommended Citation}

Mallett, Christopher A. and Stoddard Dare, Patricia A., "Parental Divorce: A Protection from Later Delinquency for Maltreated Children" (2009). Social Work Faculty Publications. 1.

https://engagedscholarship.csuohio.edu/clsowo_facpub/1

This Article is brought to you for free and open access by the School of Social Work at EngagedScholarship@CSU. It has been accepted for inclusion in Social Work Faculty Publications by an authorized administrator of EngagedScholarship@CSU. For more information, please contact library.es@csuohio.edu. 


\title{
Parental Divorce: A Protection from Later Delinquency for Maltreated Children
}

\author{
PATRICIA STODDARD DARE and CHRISTOPHER A. MALLETT \\ School of Social Work, Cleveland State University, Cleveland, Obio, USA
}

\begin{abstract}
Family structure and maltreatment (abuse and neglect) have been identified as predictors of youth delinquency, although the relationship is not clear. This article furthers this research by studying a sample of maltreated children $(n=250)$ in one Midwest county, and through a multiple regression analysis of many risk factors, the study identified only one significant delinquency variable that made delinquency less likely _ children who experience parental divorce. Some established risk factors were surprisingly found not to be predictive of later delinquency: minority race, one-parent families, youth substance abuse, recurrent maltreatment, and youth bebind in academic grade level. Implications for the family studies and juvenile justice fields are set forth.
\end{abstract}

KEYWORDS maltreatment, divorce, delinquency, family

The deleterious effects of divorce on children have been well documented (Amato, 2001; Amato \& Keith, 1991). Indeed, children of divorce experience problems with social relationships, self-concept, psychological adjustment, academic achievement, and conduct (Amato, 2001). One of the more serious issues linked to family dissolution is juvenile delinquency. Although the role of divorce has been widely studied in relationship to juvenile delinquency (Price \& Kunz, 2003; Wells \& Rankin, 1991), the path to juvenile delinquency among victims of child maltreatment who have experienced parental divorce has not been widely studied (Heck \& Walsh, 2000). As juvenile delinquency, child maltreatment, and divorce rates continue to climb, it is important to evaluate the possible interrelationship of these serious issues.

Address correspondence to Patricia Stoddard Dare, Assistant Professor, School of Social Work, Cleveland State University, 2121 Euclid Avenue, \#CB320, Cleveland, OH 44115-2214, USA. E-mail: p.stoddarddare@csuohio.edu 
This article briefly recounts the literature regarding delinquency, child maltreatment, and divorce. Following this, methodology and findings from a unique study that evaluates possible factors that predict future delinquency among a sample of maltreated youth are presented. The article concludes with discussion and implications of these findings for the family field.

\section{JUVENILE DELINQUENCY AND MALTREATMENT}

Juvenile delinquency has been a concern, to varying degrees, for decades (Roberts, 2004). Today, of the 1,615,400 youths adjudicated delinquent nationwide in 2002 (Stahl, 2006), a total of 350,000 were held in 591 detention centers (Holman \& Ziedenberg, 2006; Sickmund, Sladky, \& Wang, 2004), and 102,300 were held in 2,964 correctional facilities (Sickmund, 2006). On an average day in the United States, 54,500 youths are incarcerated in this country's detention or correctional institutions (Office of Juvenile Justice and Delinquency Prevention, 2003; Sickmund et al., 2004). These detentions and incarcerations harm the youth and their family relationships and make it more likely the youth will continue delinquent and offending activities (Benda \& Tollet, 1999; Holman \& Ziedenberg, 2006; Torres \& Ooyen, 2002).

Although no single factor is responsible for delinquency (Maas, Herrenkohl, \& Sousa, 2008; Preski \& Shelton, 2001; Turner, Hartman, Exum, \& Cullen, 2007; D. C. Widom \& Maxfield, 2001), there exist multiple risks in children's backgrounds including deficits in family, school, and neighborhoods (Hay, Fortson, Hollist, Altheimer, \& Schaible, 2006; Heilbrun, Goldstein, \& Redding, 2005; Howell, 2003; Loeber \& Farrington, 2001; Mears \& Aron, 2003; Stouthamer-Loeber, Wei, Homish, \& Loeber, 2002). Some established delinquency risk factors include gender (Loper, 1999; Smith \& Thornberry, 1995; C. S. Widom, 1991), minority race (Tracy, Wolfgang, \& Figlio, 1990), poverty (Brown, 1984; D. C. Widom \& Maxfield, 2001), early childhood behavior problems (Buka \& Earls, 1993; Howing, Wodarski, Kurtz, Gaudin, \& Herbst, 1990; Loeber \& Dishion, 1983), impaired child cognitive functioning (Buka \& Earls, 1993; Yoshikawa, 1994), youth and family substance abuse (Rapp-Palicchi \& Roberts, 2004; Teplin, Abram, McClelland, Dulcan, \& Mericle, 2002), and poor family functioning (C. S. Widom, 1991).

These risk factors tend to be cumulative and to have interactive effects, making prediction challenging for practitioners (Ford, Chapman, Hawke, \& Albert, 2007; Lemmon, 2006). However, a history of maltreatment (being a victim of abuse or neglect) continues to be found even in the presence of these other risk factors (Lemmon, 1999; Maxfield \& Widom, 1996; Smith \& Thornberry, 1995; Wiebush, McNulty, \& Le, 2000). Currently, a public policy concern is that these maltreated children constitute between $40 \%(640,000)$ and $60 \%(960,000)$ of the 1.6 million youth adjudicated delinquent annually (Currie \& Tekin, 2006; Ford et al., 2007; Loeber \& Farrington, 2001; 
Preski \& Shelton, 2001; Stahl, 2006). Although the link between maltreatment and delinquency is complicated (Smith \& Thornberry, 1995), these offending youth pose a substantial challenge to numerous social policy systems.

\section{Family Structure}

Divorce within families is quite common today in the United States (Heck \& Walsh, 2000). As of 2003, $43 \%$ of all custodial mothers and $56 \%$ of all custodial fathers were either separated or divorced. The percentage of the population that is divorced has steadily increased when viewed annually- $6 \%$ in $1980,8 \%$ in 1990 , and $10 \%$ in 2000 - with up to $50 \%$ of all marriages ending in divorce (Price \& Kunz, 2003; U.S. Census Bureau, 2006).

In previous research that has identified a link between poor family functioning and delinquency, broken homes (including divorce) have been widely studied as a cause of later juvenile delinquency adjudication (Amato \& Keith, 1991; Patterson, Reid, \& Dishon, 1992; Price \& Kunz, 2003; Rebellon, 2002; Reifman, Villa, Amans, Rethinam, \& Telesca, 2001; Wells \& Rankin, 1991). However, there is still not a consensus as to the impact these family changes have on delinquency rates (Degarmo \& Forgatch, 2005; Heck \& Walsh, 2000), although three out of four youth in state correctional facilities experienced a parental divorce, separation, or their parents never marrying (Price \& Kunz, 2003). Previous research that has tried to provide clarity included studies that broadly defined families as intact or not (Rebellon, 2002), defined these changes as marital transitions (Degarmo \& Forgatch, 2005), used smaller and unrepresentative samples (Sokol-Katz, Dunham, \& Zimmerman, 1997), and used self-reports of delinquency (Kaufman, 2000), all with varying external validity limitations for the field.

Others have attempted to organize and understand the research findings. Kunz (1992) reviewed the literature and found that many studies concluded that divorce has negative consequences for youth delinquent acts. Conversely, many studies found no difference for children in intact homes (Kunz, 1992). Wells and Rankin (1991) conducted a meta-analysis of literature and found that youth from broken homes are slightly more likely to be adjudicated delinquent (10-15\% higher than intact families) but did not find consistent evidence of severe offending by these youth. Price and Kunz (2003) found in a meta-analysis of 72 studies that children from divorced homes have higher delinquency rates compared to children from intact homes. Heck and Walsh (2000) measured both delinquency and maltreatment more comprehensively and found that when controlling for family structure, the maltreatment to delinquency risk was significant, whereas Rebellon (2002) used a national probability sample of adolescents and identified that divorce experienced by younger children might be a stronger predictor of later delinquency than previous research had found. 
To date, there look to be no published studies utilizing comparative samples of children who have been victims of maltreatment and their later delinquency outcomes. Previous literature used juvenile delinquent populations, which did include maltreatment victims, and other studies used youth with divorced-parent families and delinquent populations.

\section{Summary of Literature Review}

To summarize, juvenile delinquency is an expansive and damaging problem. Poor family functioning is a known risk factor for youth delinquency. Victims of child maltreatment are overrepresented among juvenile delinquents. Although risk factors for juvenile delinquency, including poor family functioning, have been previously identified, predicting (via risk or less risk) future delinquency among victims of child maltreatment is unique to this study.

This study continues these inquiries of delinquency risk and asks which of six factors (race, marital status, family structure, substance abuse disorder, recurrent maltreatment, and school grade behind) are significantly predictive of later youth delinquency adjudication among a random sample of maltreated children. Findings from this study will help professionals who work with at-risk families, families who have experienced divorce, and maltreated children identify risk and protective factors for delinquency and employ appropriate interventions to help prevent future delinquency.

\section{METHOD}

\section{Research Design and Sampling}

This study utilized a nonconcurrent group design. The study's population was all children who experienced maltreatment (substantiated abuse or neglect) in one midwest county between 1990 and $2004(N=23,070)$. From this County Children's Services population, one randomly drawn sample $(n=125)$ and one matched sample of children $(n=125)$ were studied in total $(n=250)$.

The first group of 125 youth was chosen from the population by first identifying a subset of all maltreated children-those who after maltreatment was substantiated were adjudicated delinquent by the County Juvenile Court in calendar years 2005 and 2006 (from a population of 790 delinquency adjudications). To determine delinquency, the County Juvenile Court provided the County Children's Services a list of all youth chosen for this group that the Court judges adjudicated delinquent. Reliability checks with identifying information were provided between public entities to ensure accuracy. From this 2-year frame, a simple random sample of delinquent youth (with maltreatment histories) was drawn for the study's first group. 
Next, a matched cohort group from the population was identified, including only those maltreated youth who were not adjudicated delinquent by the County Juvenile Court. This group was identified by using the first group's characteristics and matching on the following established delinquency risk factor variables: gender; age in years (on January 1, 2007), and calendar year of first documented substantiated maltreatment.

\section{Data Collection}

The County Children's Services Agency provided copies of case files for the children and families involved in the study. These files were deidentified and the study received university institutional review board approval. These family case files included intake and assessments, referrals, investigation chronology, investigation findings, family history records, client running logs, and central registry conclusions. Secondary data analysis of these archival records was utilized to measure the variables of interest. Intercoder reliability of this data entry and coding was high (.96).

\section{Measurements}

Six independent variables were utilized in this analysis. All variables were measured categorically: race (African-American $=1$, Caucasian $=2$, HispanicAmerican $=3$ ), marital status $($ divorced $=1$, never divorced $=2$, never married $=3$ ), family structure (one parent or two parents), youth substance abuse disorder (yes or no), number of substantiated maltreatment (abuse or neglect) child welfare investigation findings (one or two $=1$, three or more $=2$ ), and behind at least one grade level in school (yes or no). One dependent variable was measured: delinquency adjudication by the juvenile court (yes or no).

\section{Data Analysis}

Logistic regression analysis was used to investigate which independent variables (race, marital status, family structure, substance abuse disorder, recurrent maltreatment, and school grade behind) predict future delinquency among victims of child maltreatment. Because this investigation is exploratory in nature, a forward stepping method was used. Data were screened for missing data and outliers. A preliminary multiple regression was conducted to calculate Mahalanobis distance and to examine multicollinearity among the predictors. Tolerance for all variables was greater than .1, indicating multicollinearity was not a problem. One case was eliminated as an outlier.

Bivariate logistic regression was used to determine which variables would be entered into the multivariate model-identifying all six to be 
included. Variables significant in the bivariate mode at less than .1 were included in the multivariate model. Multiple binary logistic regression was then performed (Indicator $=$ last).

\section{RESULTS}

The majority of youth were Caucasian (55.3\%; minority youth, 44.7\%) and lived in one-parent homes (65.9\%; two-parent homes, 34.1\%), with over $80 \%$ of these youth experiencing either a parental divorce or having their parents never marry (parents who remained married, 19.3\%). Approximately one in six of the youth had a substance abuse disorder, were behind one or more academic grades in school, or both; children's services found these youth were maltreated (abused or neglected) an average of three separate times (see Table 1).

Regression results indicated the overall model fit of one predictor, marital status $(-2 \log$ likelihood $=187.19)$, was statistically reliable in distinguishing delinquency status, $\chi^{2}(10, N=188)=70.358, p=.001$. The model correctly classified $72.3 \%$ of cases. Regression coefficients are presented in Table 2 . Wald statistics indicated that marital status-specifically youth from divorced families-significantly protects from later delinquency adjudication. Other predictive variables were not found to be significantly related to delinquency-race, family structure, youth substance abuse disorder, recurrent maltreatment, and behind in school grade level.

TABLE 1 Descriptive Profile

\begin{tabular}{lc}
\hline Variable & Frequency (\%) \\
\hline Race & \\
African-American & 28.5 \\
Caucasian & 55.3 \\
Hispanic-American & 7.7 \\
Other & 8.5 \\
Marital status & \\
Divorced & 40.5 \\
Never divorced & 19.3 \\
Never married & 40.2 \\
Family structure & \\
One parent & 65.9 \\
Two parents & 34.1 \\
Youth substance abuse disorder & 16.5 \\
Number of substantiated children's & $3.1(M ; 2.1 S D)$ \\
$\quad$ services findings (recurrent) & 17.4 \\
Behind one or more grades in school & \\
\hline
\end{tabular}


TABLE 2 Regression Coefficients

\begin{tabular}{|c|c|c|c|c|c|}
\hline Variable & $B$ & Wald & $d f$ & $p$ & Odds ratio \\
\hline Race & & 2.71 & 3 & .44 & - \\
\hline African-American & 0.63 & 1.06 & 1 & .30 & 1.87 \\
\hline Caucasian & 0.64 & 1.21 & 1 & .27 & 1.9 \\
\hline Hispanic-American & 1.39 & 2.62 & 1 & .106 & 4.03 \\
\hline Other & - & - & - & - & - \\
\hline Marital status & & 7.45 & 2 & .02 & \\
\hline Divorced & -1.11 & 6.70 & 1 & .01 & 0.33 \\
\hline Never divorced & -0.04 & 0.005 & 1 & .94 & 0.96 \\
\hline Never married & - & - & - & - & - \\
\hline Family structure (one parent) & 0.68 & 2.36 & 1 & .13 & 1.97 \\
\hline Youth substance abuse disorder & 21.61 & 0.00 & 1 & .99 & 0.00 \\
\hline Recurrent maltreatment & 0.42 & 1.28 & 1 & .26 & 1.52 \\
\hline Behind one or more grades in school & -0.39 & 0.46 & 1 & .50 & 0.68 \\
\hline
\end{tabular}

\section{DISCUSSION}

This study analyzed the relationship among six possible risk factors and later youth delinquency among a sample of maltreated youth. For this sample of maltreated children, the only risk factor that was significantly related to later delinquency was whether their parents divorced-here this divorce outcome made later adjudication less likely for the youth when compared to youth from never-married families. This is somewhat surprising when reviewing more recent family functioning literature, which found higher delinquency rates for children and youth, with and without maltreatment histories, who experienced parental divorce (Heck \& Walsh, 2000; Price \& Kunz, 2003; Rebellon, 2002). These differential outcomes may be explained in that very limited research to date has tried to explain the maltreatment, delinquency, and family structure connections. Those who did used samples of youth that were all under juvenile court probation (some with maltreatment histories; Heck \& Walsh, 2000), whereas this study used comparative delinquent and nondelinquent groups, all with maltreatment histories. Although this study's results have limitations, the findings support the notion that family divorce and youth delinquency adjudication are linked. A unique addition is that these findings are from a sample of children who all experienced maltreatment-half of whom were later adjudicated delinquent. This allows for more sophisticated comparisons between these two groups. These findings suggest this link between parental divorce and later juvenile delinquency is a protective relationship (Heck \& Walsh, 2000).

Also of unique interest is that this study's results did not confirm numerous established delinquency risk factors-minority race, one-parent family structure, youth substance abuse disorders, recurrent maltreatment, and youth behind in academic grade level. This suggests that the risk factors 
for later delinquency among maltreated youth might indeed differ from risk factors for youth who have not been maltreated.

Other issues might impact the interpretation of these findings. For example, minority youth are consistently overrepresented within the juvenile justice system (disproportionate minority contact phenomenon) and in this study sample. This is a widely acknowledged and relevant concern (Poe-Yamagata \& Jones, 2000). Another pertinent issue is that one-parent experiences represent a larger percentage of family structure for adjudicated delinquent youth when compared to nondelinquent youth, although the link is somewhat complicated (Office of Juvenile Justice and Delinquency Prevention, 2003). This study did not find this link, either because it does not exist within the sample reviewed or because of methodological limitations. Similarly, youth who abuse substances and are struggling in school performance are at higher risk for delinquency (American Bar Association, 2007; Mears \& Aron, 2003). These factors were not found here as significant predictors, but these variables deserve further investigation, particularly by more broadly studying and measuring cognitive youth impairments that might be impacting school outcomes.

These results should be reviewed in light of research that has found delinquency to be a cumulative outcome for the child, with these risk and protective factors having interactive effects (Ford et al., 2007; Hawkins et al., 2000; Wiebush et al., 2000). Predicting delinquency is a difficult research-topractice task for professional fields involved, and one that should not be performed in a vacuum of understanding. However, identifying maltreated children who are most at risk for later delinquency is an important endeavor. This study supports the notion that maltreated children who experience parental divorce are less at risk than maltreated children whose parents never married-with divorce acting as a protective factor. Fortunately, delinquency adjudication is not the inevitable outcome for all maltreated children; risk and protective factors interact to help minimize these harsh outcomes. Additional protective factors have been identified by other researchers to include a strong parent-child attachment, youth having a close relationship with at least one adult, clear and consistent family norms, increased parent monitoring, and youth involvement in prosocial recreational activities (Hawkins et al., 2000; Howell, 2003), although these factors were not studied in this project.

Continued research and preventative interventions targeting this population are important for these children, their families, and the social policy systems designed to support at-risk families and prevent juvenile delinquency outcomes. For example, it might be useful to utilize a court-supported interventionsuch as a parent education program focused on divorce, parents who do not marry, and parental conflict (Shifflett \& Cummings, 1999). Intervention programs also exist that are designed to reduce aggression, anxiety, and depression, and enhance social competency among children whose parents 
are divorcing and might extend to parents who chose not to marry (Brown et al., 1994).

\section{Limitations}

These results have some limitations. First, the findings are of a relatively small sample from only one Midwest county of maltreated children, served by one children's services agency, limiting the external validity. Although replication is necessary, some findings use is in order. Second, because of the smaller sample size, variations in the model might be too small to produce stable estimates-the model should be further tested with larger groups. Third, variables chosen for inclusion and measurement in this study were based on previous research literature outcomes. There is a chance that other variables could have been found to be statistically significant (or not) in predicting later delinquency, but were not utilized. Finally, this study employed secondary data analysis. Although reliability checks were performed, the extent to which the original data files contained errors is unknown.

\section{Conclusions}

This study found that within a sample of maltreated children there were interesting risk and protective factor findings in predicting later delinquency adjudication. Traditional risk factors for juvenile delinquency were not found to be significant in this study, whereas parental divorce, compared to parents not marrying, was found to lessen this juvenile court outcome. Although replication of this small study is certainly in order, findings from this study point to some important practical considerations for professionals who work with children and families. It might be prudent for these professionals to develop a specialized treatment plan for children with and without divorced parents who have a documented history of maltreatment. It might be the case that traditional interventions to prevent juvenile delinquency might have a different focus with victims of maltreatment who have experienced divorce. Future research should examine the effectiveness of various preventative interventions with this subset of children and youth.

\section{REFERENCES}

Amato, P. R. (2001). Children of divorce in the 1990's: An update of the Amato and Keith (1991) meta-analysis. Journal of Family Psychology, 15, 355-370.

Amato, P. R., \& Keith, B. (1991). Parental divorce and well-being of children: A meta-analysis. Psychological Bulletin, 110, 26-46.

American Bar Association. (2007). ABA president elect youth at risk initiative. Retrieved September 15, 2008, from http://www.abanet.org/youthatrisk/ 
Benda, B. B., \& Tollet, C. L. (1999). A study of recidivism of serious and persistent offenders among adolescents. Journal of Criminal Justice, 27, 111-126.

Brown, J. H., Portes, P., Cambron, M., Zimmerman, D., Rickert, V., \& Bissmerger, C. (1994). Families in transition: A court-mandated divorce adjustment program for parents and children. Juvenile and Family Court Journal, 45, 27-32.

Brown, S. E. (1984). Social class, child maltreatment, and delinquent behavior. Criminology, 22, 259-278.

Buka, S., \& Earls, F. (1993). Early determinants of delinquency and violence. Health Affairs (Winter), 46-64.

Currie, J., \& Tekin, E. (2006). Does child abuse cause crime? Retrieved September 15, 2008, from http://aysps.gsu.edu/publications/2006/downloads/CurrieTekin_ ChildAbuse.pdf

Degarmo, D. S., \& Forgatch, M. S. (2005). Early development of delinquency within divorced families: Evaluating a randomized preventive intervention trial. Developmental Science, 8, 229-239.

Ford, J. D., Chapman, J. F., Hawke, J., \& Albert, D. (2007). Trauma among youth in the juvenile justice system: Critical issues and new directions. Delmar, NY: National Center for Mental Health and Juvenile Justice. Retrieved September 16, 2008, from www.ncmhjj.com

Hawkins, J., Herrenkohl, T., Farrington, D., Brewer, D., Catalano, R. F., Harachi, T. W., et al. (2000). Predictors of youth violence. Washington, DC: Office of Juvenile Justice and Delinquency Prevention. Retrieved September 15, 2008, from http:// www.ncjrs.org/html.ojjdp/jjbul2000_04_5/contents/html

Hay, C., Fortson, E., Hollist, D., Altheimer, I., \& Schaible, L. (2006). The impact of community disadvantage on the relationship between the family and juvenile crime. Journal of Research in Crime and Delinquency, 43, 326-356.

Heck, C., \& Walsh, A. (2000). The effects of maltreatment and family structure on minor and serious delinquency. International Journal of Offender Therapy and Comparative Criminology, 44, 178-193.

Heilbrun, K., Goldstein, N., \& Redding, R. (2005). Juvenile delinquency: Prevention, assessment, and intervention. New York: Oxford University Press.

Holman, B., \& Ziedenberg, J. (2006). The dangers of detention: The impact of incarcerating youth in detention and other secure congregate facilities. Baltimore: Annie E. Casey Foundation.

Howell, J. C. (2003). Preventing and reducing juvenile delinquency: A comprehensive framework. Thousand Oaks, CA: Sage.

Howing, P. T., Wodarski, J. S., Kurtz, P. D., Gaudin, J. M., \& Herbst, E. M. (1990). Child abuse and delinquency: The empirical and theoretical links. Social Work, 35, 244-249.

Kaufman, J. M. (2000, November). Explaining violence by black and white adolescents: An application of general strain theory. Paper presented at the conference of the American Society of Criminology, San Francisco.

Kunz, J. (1992). The effects of divorce on children. In S. J. Bahr (Ed.), Family research: A sixty-year review, 1930-1990 (Vol. II, pp. 325-376). New York: Lexington Press.

Lemmon, J. H. (1999). How child maltreatment affects dimensions of juvenile delinquency in a cohort of low-income urban males. Justice Quarterly, 16, 357-376. 
Lemmon, J. H. (2006). The effects of maltreatment recurrence and child welfare on dimensions of delinquency. Criminal Justice Review, 31(1), 5-32.

Loeber, R., \& Dishion, T. (1983). Early predictors of male delinquency: A review. Psychological Bulletin, 94, 68-99.

Loeber, R., \& Farrington D. P. (2001). The significance of child delinquency. In R. Loeber \& D. P. Farrington (Eds.), Child delinquents: Development, intervention, and service needs (pp. 1-22). Thousand Oaks, CA: Sage.

Loper, A. (1999). Female juvenile delinquency: Risk factors and promising interventions (NCJ Manuscript No. 183499). Washington, DC: Office of Juvenile Justice and Delinquency Prevention.

Maas, C., Herrenkohl, T. I., \& Sousa, C. (2008). Review of research on child maltreatment and violence in youth. Trauma, Violence, \& Abuse, 9, 56-67.

Maxfield, J. G., \& Widom, C. S. (1996). The cycle of violence: Revisited six years later. Archives of Pediatric and Adolescent Medicine, 150, 390-395.

Mears, D., \& Aron, L. (2003). Addressing the needs of youth with disabilities in the juvenile justice system: The current state of knowledge. Washington, DC: Urban Institute, Justice Policy Center.

Office of Juvenile Justice and Delinquency Prevention. (2003). Census of juveniles in residential placement databook. Washington, DC: Author. Retrieved September 20, 2008, from http://ojjdp.ncjrs.org/ojstatbb/cjrp/asp/State_Adj.asp

Patterson, G. R., Reid, J. B., \& Dishion, T. J. (1992). A social interactional approach: Antisocial boys (Vol. 4). Eugene OR: Castalia.

Poe-Yamagata, E., \& Jones, M. (2000). And justice for some. Washington, DC: Building Blocks for Youth. Retrieved September 10, 2008, from http:// www.buildingblocksforyouth.org/justiceforsome/

Preski, S., \& Shelton, D. (2001). The role of contextual, child, and parent factors in predicting criminal outcomes in adolescence. Issues in Mental Health Nursing, 22, 197-205.

Price, C., \& Kunz, J. (2003). Rethinking the paradigm of juvenile delinquency as related to divorce. Journal of Divorce \& Remarriage, 39(1), 109-133.

Rapp-Palicchi, L., \& Roberts, A. (2004). Mental illness and juvenile offending. In A. Roberts (Ed.), Juvenile justice sourcebook: Past, present, and future (pp. 289-308). New York: Oxford University Press.

Rebellon, C. J. (2002). Reconsidering the broken homes/delinquency relationship and exploring its mediating mechanism(s). Criminology, 40, 103-135.

Reifman, A., Villa, L., Amans, J., Rethinam, V., \& Telesca, T. (2001). Children of divorce in the 1990's: A meta-analysis. Journal of Divorce \& Remarriage, 36(1-2), 27-41.

Roberts, A. R. (2004). Juvenile justice sourcebook: Past, present, and future. New York: Oxford University Press.

Shifflett, K., \& Cummings, E. M. (1999). A program for educating parents about the effects of divorce and conflict on children: An initial evaluation. Family Relations, 48, 79-89.

Sickmund, M. (2006, June). Juvenile residential facilities census, 2002: Selected findings. Washington, DC: U.S. Department of Justice, OJJDP.

Sickmund, M., Sladky, T. J., \& Wang, W. (2004). Census of juveniles in residential placement databook. Retrieved September 16, 2008, from http://www.ojjdp. ncjrs.org/ojstatbb/cjrp/ 
Smith, C., \& Thornberry, T. P. (1995). The relationship between childhood maltreatment and adolescent involvement in delinquency. Criminology, 33, 451-481.

Sokol-Katz, J., Dunham, R., \& Zimmerman, R. (1997). Family structure versus parental attachment in controlling adolescent deviant behavior: A social control model. Adolescence, 32, 199-215.

Stahl, A. L. (2006). Delinquency cases in juvenile court, 2002. Washington, DC: U.S. Department of Justice, Office of Juvenile Justice and Delinquency Prevention. Retrieved September 10, 2008, from http://www.ncjrs.gov/pdffiles1/ojjdp/ fs200602.pdf

Stouthamer-Loeber, M., Wei, E., Homish, D., \& Loeber, R. (2002). Which family and demographic factors are related to both maltreatment and persistent serious juvenile delinquency? Children's Services: Social Policy, Research, and Practice, 5, 261-272.

Teplin, L., Abram, K., McClelland, G., Dulcan, M., \& Mericle, A. (2002). Psychiatric disorders in youth in juvenile detention Archives of General Psychiatry, 59, 1133-1143.

Torres, C., \& Ooyen, M. V. (2002). Briefing paper. New York: Committee on Youth Services. Retrieved September 15, 2008, from http://webdocs.nyccouncil.info/ attachments $/ 56612 . h t m ? C F I D=1677675 \&$ CFTOKEN $=84562487$

Tracy, P. E., Wolfgang, M. E., \& Figlio, R. M. (1990). Delinquency careers in two birth cohorts. New York: Plenum.

Turner, M., Hartman, J., Exum, M., \& Cullen, F. (2007). Examining the cumulative effects of protective factors: Resiliency among a national sample of high-risk youths. Journal of Offender Rehabilitation, 46(1-2), 81-111.

U.S. Census Bureau. (2006). Marital status. Washington, DC: Author. Retrieved September 16, 2008, from http://factfinder.census.gov/servlet/ACSSAFFPeople?_event=\&geo_

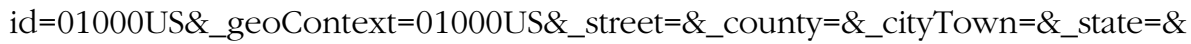
$\_z i p=\& \_l a n g=e n \& \_s s e=0 n \& A c t i v e G e o D i v=\& \_u s e E V=\& p c t x t=f p h \& p g s l=010 \&$ _ submenuId=people_11\&ds_name=ACS_2006_SAFF\&_ci_nbr=null\&qr_name=null $\&$ reg=null\%3Anull\&_keyword=\&_industry=

Wells, L. E., \& Rankin, J. H. (1991). Families and delinquency: A meta-analysis of the impact of broken homes. Social Problems, 38, 71-93.

Widom, C. S. (1991). The role of placement experiences in mediating the criminal consequences of early childhood victimization. American Journal of Orthopsychiatry, 61, 195-209.

Widom, D. C., \& Maxfield, M. G. (2001). Research in brief: An update on the "cycle of violence." Washington, DC: U.S. Department of Justice, Office of Justice Programs, National Institute of Justice.

Wiebush, R., McNulty, B., \& Le, T. (2000). Implementation of the intensive communitybased aftercare program (Bulletin). Washington, DC: Department of Justice, Office of Juvenile Justice and Delinquency Prevention.

Yoshikawa, H. (1994). Prevention as cumulative protection: Effects of early family support and education on chronic delinquency and its risks. Psychological Bulletin, $115,28-54$. 